\title{
Clinical and pathological features of five-year survivors after pancreatectomy for pancreatic adenocarcinoma
}

\author{
Kenjiro Kimura ${ }^{*}$, Ryosuke Amano ${ }^{1}$, Bunzo Nakata², Sadaaki Yamazoe' ${ }^{1}$ Keiichiro Hirata' ${ }^{1}$, Akihiro Murata', \\ Kotaro Miura', Kohei Nishio', Toshiki Hirakawa', Masaichi Ohira ${ }^{1}$ and Kosei Hirakawa'
}

\begin{abstract}
Background: Clinical factors determining short-term survival after pancreatectomy have been well studied, but factors predicting long-term survival with curative resection are poorly understood in pancreatic carcinoma. Our objective was to identify clinical and pathological features of five-year disease-free survivors after surgical resection of pancreatic adenocarcinoma.

Methods: The clinical and pathological data from 147 patients who underwent a potentially curative resection for pancreatic adenocarcinoma at our institution between 1988 and 2012 were retrospectively analyzed.

Results: Of 147 patients, 18 survived for more than five years after surgery without disease recurrence. A univariate analyses demonstrated that: two or fewer lymph node metastases $(P=0.014)$, a preoperative serum carbohydrate antigen 19-9 (CA19-9) level of $40 \mathrm{U} / \mathrm{mL}$ or less $(P=0.0018)$, an absence of intrapancreatic nerve invasion $(P=0.028)$, and undergoing an $\mathrm{RO}$ resection $(P=0.011)$ were significantly associated with five-year survival. A logistic regression model identified the following independent cancer-related predictors of five-year survivors: having two or fewer lymph node metastases (odds ratio (OR): 6.02 ; $95 \%$ confidence interval $(\mathrm{Cl}): 1.08$ to $112.98 ; P=0.0385$ ), a preoperative serum CA19-9 level of $40 \mathrm{U} / \mathrm{mL}$ or less (OR: 5.02; $95 \%$ Cl: 1.68 to $16.48 ; P=0.0036$ ), and undergoing an R0 resection (OR: $3.63 ; 95 \% \mathrm{Cl}: 1.12$ to $14.28 ; P=0.0316)$.

Conclusions: We conclude that number of lymph node metastases being two or less, a preoperative serum CA19-9 level of $40 \mathrm{U} / \mathrm{mL}$ or less, and undergoing an R0 resection may be independent predictive factors to identify actual five-year survivors after pancreatectomy for pancreatic adenocarcinoma.
\end{abstract}

Keywords: Pancreatic carcinoma, Five-year survivors, CA19-9, R0, Lymph node metastasis

\section{Background}

Pancreatic carcinoma is the fourth leading cause of death from cancer and is responsible for 43,000 deaths per year in the United States [1]. The prevalence of pancreatic cancer in Japan has also increased in the last decade to become the fifth leading cause of cancer death in men, and the sixth in women [2]. This malignancy is devastating, with a five-year overall survival rate of approximately $5 \%$ [1]. The only potentially curative treatment for pancreatic cancer is surgical resection. However, only a small number

\footnotetext{
*Correspondence: kenjiro@med.osaka-cu.ac.jp

'Department of Surgical Oncology, Osaka City University Graduate School of Medicine, 1-4-3 Asahimachi, Abeno-ku, Osaka 545-8585, Japan

Full list of author information is available at the end of the article
}

of patients (between 15 and 20\%) present with a resectable tumor at the time of diagnosis [3]. Moreover, the prognosis even after potentially curative resection is considered to be poor. The following characteristics have been reported to be significant prognostic factors for patient survival after tumor resection: age [4], tumor size [4-6], lymph node metastasis [4-6], surgical margin status [7-9], preoperative serum CA19-9 level [9-11], and tumor grade [7]. Clinical factors determining short-term survival after pancreatectomy have been well studied, but prognostic factors predicting long-term survival with curative resection are poorly understood [12-14].

In the earlier studies, it was difficult to discuss factors related to five-year survival because of the high

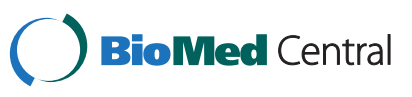


postoperative mortality. Today, the surgical procedure can be performed safely, and the postoperative mortality in some specialized pancreatic centers is reported to be less than 5\% [15-17]. In the many previous reports, the follow-up period was within five years, but precise data on the long-term survival and prognostic factors can be obtained by analysis not only of actuarial data, but also of data of patients who achieve actual long-term survival of five years or more.

The aim of this study was to identify the clinical and pathological features of five-year survivors after surgical resection of pancreatic ductal carcinoma. This study could aid oncologists and surgeons in determining which characteristics or clinicopathological factors suggest an increased possibility of five-year survival after pancreatic resection for pancreatic carcinoma.

\section{Methods}

\section{Patients}

A total of 195 patients who underwent pancreatectomy for pancreatic ductal carcinoma at our institution between January 1988 and October 2012 were studied. Informed consent was obtained from all patients to use the specimens for this study according to the institutional rules of the hospital. All patients were histologically confirmed to have the common type of invasive ductal carcinoma of the pancreas. Any patients with neuroendocrine carcinoma, mucinous cystic carcinomas, or intraductal papillary mucinous carcinomas were excluded. Of the 195 patients, 48 patients were excluded for the following reasons: 42 censored cases, composed of four patients who were lost to follow-up during the observation period and 38 patients who were alive within five years after the operation; four due to postoperative mortality within 30 days; and two were five-year survivors with recurrence disease. The data from the remaining 147 patients, who were fiveyear survivors without disease recurrence (five-year survivors) and died within five years after surgery (short-term survivors), was retrospectively analyzed. The demographic and clinical variables included age, sex, preoperative serum CA19-9 level, and tumor location. In patients with preoperative jaundice, the data after the jaundice was reduced was used as the preoperative serum CA19-9 values. In patients with jaundice at our medical center, endoscopic or percutaneous bile duct drainage is usually performed. The CA19-9 value in all patients was the value after total bilirubin was reduced to under $5 \mathrm{mg} / \mathrm{dL}$. All patients had presented with resectable localized disease without distant metastasis. None of the patients received neoadjuvant therapy before surgery. Fourteen patients had intraoperative radiation therapy (IORT), and 20 patients received adjuvant chemotherapy with gemcitabine. All patients were followed up on for survival, and the median follow-up period was 14.5 (2.1 to 170.2) months.

\section{Surgery and pathology}

Surgery involved standard or subtotal stomach-preserving pancreaticoduodenectomy in 90 patients (61.2\%), distal pancreatectomy in 49 (33.3\%), and total pancreatectomy in eight (5.4\%). Regional lymph node dissection was performed in all patients and the median number of resected lymph nodes was 24 (range: 2 to 100). The resected specimens were fixed in $10 \%$ formalin at room temperature, and the size and gross appearance of the tumor were recorded. The pathologic stage of all tumor specimens was determined using the American Joint Committee on Cancer (Sixth edition) staging system [18]. Tumor differentiation was classified according to the World Health Organization's classification of either well-differentiated (Grade 1), moderately differentiated (Grade 2), poorly differentiated (Grade 3), or undifferentiated (Grade 4) [19]. A positive margin was defined as the presence of at least one cancer cell within $1 \mathrm{~mm}$ of one or more resection margins on a macroscopic examination. The pathological features that might affect prognosis were histologically assessed tumor size, serosal invasion (S), retroperitoneal tissue invasion (RP), intrapancreatic common bile duct invasion $(\mathrm{CH})$, portal vein invasion $(\mathrm{PV})$, lymph node metastasis, lymphatic invasion (LY), venous invasion (V), and intrapancreatic nerve invasion (NE), on the basis of the Japan Pancreas Society classification (Sixth edition) [20].

\section{Statistical analysis}

The clinicopathological features were compared between five-year survivors and short-term survivors. The risk factors related to survival were examined in long-term survivors. Categorical variables were compared using the $x^{2}$ test or Fisher's exact test. A receiver operating characteristics (ROC) curve was constructed to estimate the optimal cutoff value of preoperative serum CA19-9. The cutoff value was determined as the point closest to the upper left-hand corner of the graph. Variables with a significance of $P<0.05$ on a univariate analysis were included in a multivariate regression analysis to identify factors associated with long-term survival. Survival was calculated using the Kaplan-Meier method and compared between groups by the log-rank test. $P$ values $<0.05$ were considered significant. Statistical analyses were performed using SAS version 9.0 software (SAS Institute, Inc., Cary, North Carolina, United States).

\section{Results}

Characteristics of patient and tumor-related data of these 147 patients are given in Table 1 . The median overall survival of all cases was 14.4 months; short-term and five-year survivors were 12 months and 125.6 months, respectively. The actuarial three- and five-year survival rates were $18.4 \%$ and $12.2 \%$, respectively. The median 
Table 1 Patient characteristics

\begin{tabular}{|c|c|}
\hline Characteristics & Number \\
\hline \multicolumn{2}{|l|}{ Gender } \\
\hline Male & 85 \\
\hline Female & 62 \\
\hline \multicolumn{2}{|l|}{ Age (years) } \\
\hline Median (range) & 67 (33 to 85$)$ \\
\hline \multicolumn{2}{|l|}{ Tumor location } \\
\hline Head & 97 \\
\hline Body/tail & 50 \\
\hline \multicolumn{2}{|l|}{ Tumor size $(\mathrm{cm})$} \\
\hline Median (range) & $3.4(1.2$ to 18$)$ \\
\hline \multicolumn{2}{|l|}{ Surgery } \\
\hline Pancreatoduodenectomy & 90 \\
\hline Distal pancreatectomy & 49 \\
\hline Total pancreatectomy & 8 \\
\hline \multicolumn{2}{|l|}{ Histologic differentiation } \\
\hline Grade 1 & 33 \\
\hline Grade 2 & 80 \\
\hline Grade 3 & 24 \\
\hline Grade 4 & 10 \\
\hline \multicolumn{2}{|c|}{ UICC stage Union for International Cancer Control } \\
\hline IA & 1 \\
\hline $\mathrm{IB}$ & 7 \\
\hline$\| \mathrm{A}$ & 46 \\
\hline IIB & 71 \\
\hline III & 3 \\
\hline IV & 19 \\
\hline \multicolumn{2}{|l|}{ Positive lymph node } \\
\hline No & 59 \\
\hline N1 & 88 \\
\hline \multicolumn{2}{|l|}{ Resection status } \\
\hline RO & 72 \\
\hline $\mathrm{R} 1$ & 34 \\
\hline R2 & 41 \\
\hline
\end{tabular}

overall survival times of early cases (who were operated on between 19888 and 2000) and late cases (2001 to 2012) were 13.5 and 14.7 months, respectively. There are no statistical differences in survival $(P=0.65)$.

The median preoperative serum CA19-9 level of the 147 patients was $122 \mathrm{U} / \mathrm{mL}$. An ROC curve demonstrated that a preoperative serum CA19-9 level of $40 \mathrm{U} / \mathrm{mL}$ was the optimal cutoff point for five-year survival, with a sensitivity of $66.7 \%$ and a specificity of $73.6 \%$. The area under the curve (AUC) was 0.670 (Figure 1).

Of the 147 patients, 18 patients (12.2\%) survived more than five years after surgery without disease recurrence. The median age of five-year survivors (13 men, five women) was 65 years (range: 46 to 76 ). The distribution

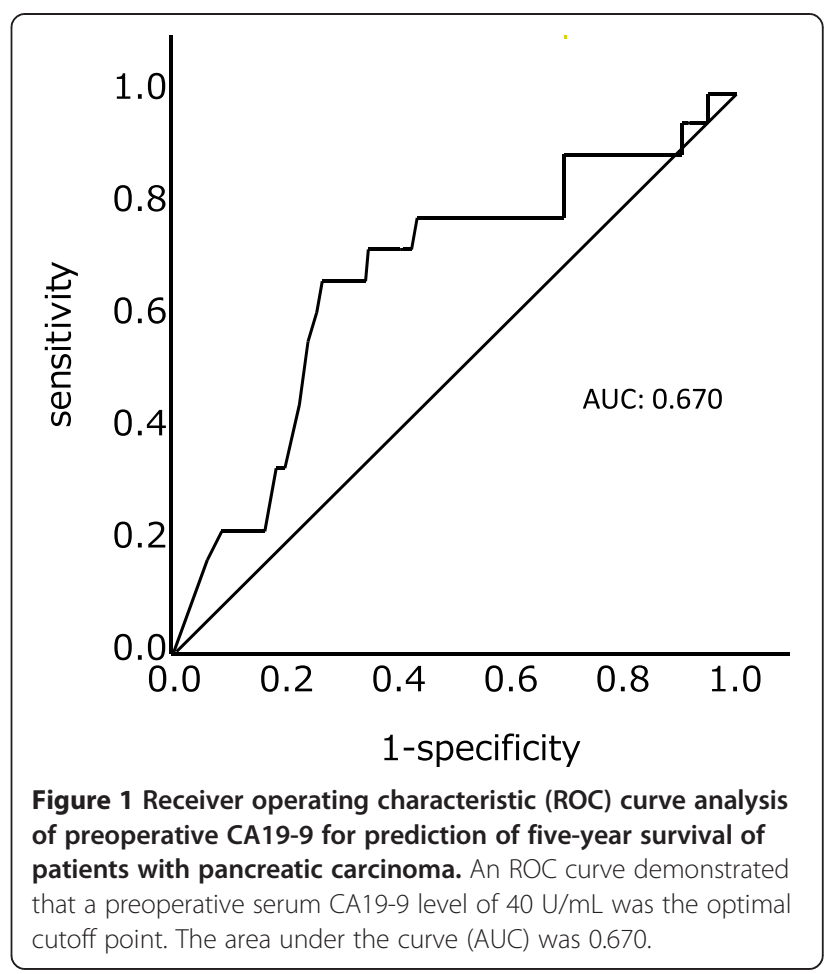

of the tumor stages according to The UICC TNM Classification (UICC (Union for International Cancer Control) Sixth) was: stage IA ( $\mathrm{n}=1 ; 5.6 \%)$; IB $(\mathrm{n}=2 ; 11.1 \%)$; IIA $(\mathrm{n}=6 ; 33.3 \%) ;$ IIB $(\mathrm{n}=9 ; 50 \%)$; and stage III or IV (none). The pancreatic resections were standard pancreaticoduodenectomy in 12 patients and distal pancreatectomy in six patients. The median tumor size was $32 \mathrm{~mm}$ (range: 12 to 55 ), including five patients (27.8\%) with tumor diameters of $20 \mathrm{~mm}$ or less. Eight patients were positive for lymph node metastasis, and all patients with positive lymph nodes had within two positive lymph nodes. Portal vein resection was performed in two patients, and R0 surgery was performed in 14 (77.8\%) patients. Tumor recurrences beyond five years after surgery were observed in four patients. The longest time for recurrence was 8.4 years after surgery (Table 2 ).

Table 3 shows the results of the univariate analysis of the factors affecting five-year survival after pancreatectomy in the 147 patients. Sex, age, tumor location, tumor size, histologic differentiation, $\mathrm{T}$ classification, $\mathrm{N}$ classification, adjuvant therapy, S, RP, CH, LY, V, portal vein resection, and IORT were evaluated, but were not significant on univariate analysis. Significant associations with fiveyear survival were observed for number of lymph node metastases being two or less $(P=0.014)$, a preoperative serum CA19-9 level cutoff of $40 \mathrm{U} / \mathrm{mL}(P=0.0018)$, the absence of $\mathrm{NE}(\mathrm{P}=0.028)$, and undergoing an $\mathrm{R} 0$ resection $(P=0.011)$.

A logistic regression model adjusted for two or fewer lymph node metastases, a preoperative serum CA19-9 
Table 2 Characteristics of five-year survivors without disease recurrence

\begin{tabular}{|c|c|c|c|c|c|c|c|c|c|c|}
\hline Age/gender & $\begin{array}{l}\text { CA19-9 } \\
(\mathrm{U} / \mathrm{mL})\end{array}$ & $\begin{array}{l}\text { Tumor } \\
\text { location }\end{array}$ & $\begin{array}{l}\text { Tumor } \\
\text { size }(\mathrm{mm})\end{array}$ & $\begin{array}{l}\text { UICC } \\
\text { stage }\end{array}$ & TNM-N & $\begin{array}{l}\text { Number of lymph } \\
\text { node metastasis }\end{array}$ & Surgery & $\mathbf{R}$ & $\begin{array}{l}\text { Outcome } \\
\text { (month) }\end{array}$ & Recurrence \\
\hline $71 / F$ & 2 & $\mathrm{~Pb}$ & 16 & IA & 0 & 0 & $\mathrm{DP}$ & 0 & $68 / A$ & None \\
\hline $76 / F$ & 65 & $\mathrm{Ph}$ & 30 & $\| B$ & 1 & 2 & PD & 0 & 69/D & None \\
\hline $72 / \mathrm{M}$ & 597 & $\mathrm{Pt}$ & 40 & $\| B$ & 1 & 2 & DP & 1 & 73/D & Dissemination \\
\hline $57 / M$ & 611 & $\mathrm{Ph}$ & 42 & $\| B$ & 0 & 0 & PD with PV & 0 & $74 / \mathrm{A}$ & None \\
\hline $73 / F$ & 3221 & $\mathrm{Pbt}$ & 32 & $\| B$ & 1 & 2 & $\mathrm{DP}$ & 0 & $78 / A$ & None \\
\hline $76 / M$ & 21 & $\mathrm{Ph}$ & 20 & $\| \mathrm{A}$ & 0 & 0 & PD & 0 & 79/D & None \\
\hline $62 / \mathrm{M}$ & 103 & $\mathrm{Ph}$ & 40 & $\| \mathrm{B}$ & 1 & 2 & PD & 0 & $85 / D$ & Lymph node \\
\hline $61 / M$ & 29 & $\mathrm{Ph}$ & 12 & $\| \mathrm{A}$ & 0 & 0 & PD & 1 & $86 / A$ & None \\
\hline $46 / M$ & 31 & $\mathrm{Ph}$ & 40 & $\| \mathrm{A}$ & 0 & 0 & PD & 0 & $89 / D$ & Liver/local \\
\hline $68 / \mathrm{F}$ & 2381 & $\mathrm{Ph}$ & 55 & $\| \mathrm{A}$ & 0 & 0 & PD & 0 & $92 / \mathrm{A}$ & None \\
\hline $73 / M$ & 39 & $\mathrm{~Pb}$ & 38 & $\| \mathrm{B}$ & 1 & 1 & $\mathrm{DP}$ & 0 & $100 / \mathrm{A}$ & None \\
\hline $60 / F$ & 34 & $\mathrm{Ph}$ & 50 & $\| B$ & 1 & 2 & PD & 0 & $108 / \mathrm{A}$ & None \\
\hline 70/M & 29 & $\mathrm{Ph}$ & 32 & IB & 0 & 0 & PD & 0 & $111 / A$ & None \\
\hline $57 / M$ & 20 & $\mathrm{Ph}$ & 30 & $\| B$ & 1 & 2 & PD with PV & 1 & $122 / D$ & Lung/skin \\
\hline $56 / M$ & 4.1 & $\mathrm{Ph}$ & 20 & $\| \mathrm{A}$ & 0 & 0 & PD & 0 & 129/D & None \\
\hline $57 / M$ & 30 & $\mathrm{~Pb}$ & 30 & $\mathrm{IB}$ & 0 & 0 & DP & 0 & $144 / \mathrm{A}$ & None \\
\hline $57 / \mathrm{M}$ & 7 & $\mathrm{~Pb}$ & 35 & $\| \mathrm{A}$ & 0 & 0 & DP & 0 & $145 / A$ & None \\
\hline $70 / \mathrm{M}$ & 2 & $\mathrm{Ph}$ & 15 & $\| B$ & 1 & 1 & PD & 1 & 170/A & None \\
\hline
\end{tabular}

$\mathrm{A}$, alive; $\mathrm{D}$, dead; $\mathrm{DP}$, distal pancreatectomy; $\mathrm{Pb}$, body of the pancreas; Pbt, body and tail of the pancreas; $\mathrm{PD}$, pancreaticoduodenectomy; $\mathrm{Ph}$, head of the pancreas; Pt, tail of the pancreas; PV, portal vein resection; R, resection status.

level cutoff of $40 \mathrm{U} / \mathrm{mL}$, resection margin status, and the absence of NE identified the following independent cancer-related predictors of five-year survivors: two or fewer lymph node metastases, (OR: 6.02, 95\% CI: 1.08 to $112.98 ; P=0.0385), \mathrm{CA} 19-9 \leq 40 \mathrm{U} / \mathrm{mL}$ (OR: $5.02 ; 95 \% \mathrm{CI}$ : 1.68 to $16.48 ; P=0.036$ ), and R0 resection (OR: 3.63; 95\% CI: 1.12 to $14.28 ; P=0.0316$ ) (Table 4).

On the basis of the multivariate analysis results, a combined analysis of the preoperative serum CA19-9 level, R0 resection, and number of lymph node metastases being two or less was performed. When each of the three predictors was counted as one point and the points were calculated for all 147 cases, a good stratified survival curve was obtained, showing the longer survival in the higher points: median survival times of three, two, one, and zero points were $39.0,17.0,8.2$, and 8.6 months, respectively $(P<0.0001)$ (Figure 2).

\section{Discussion}

The present study identified three factors (number of lymph node metastases being two or less, preoperative serum CA19-9 level of $\leq 40 \mathrm{U} / \mathrm{mL}$, and R0 resection), as being related to five-year survival after surgical resection of pancreatic ductal carcinoma. Moreover, the longest survival time was observed in patients who had all of these three factors (Figure 2). To date, prognostic factors for pancreatic carcinoma have been vigorously investigated [4-11]. However, the present study did not simply examine prognostic factors; instead, by analyzing patients who actually achieved five-year survival, factors for fiveyear survival were more accurately identified.

Tumor size has been considered an important prognostic factor for pancreatic cancer. Large surgical series showed that five-year survival rate (20 to $41 \%)$ and median survival time (23 to 38 months) of small pancreatic cancer were better than the five-year survival rate ( 1 to $20 \%$ ) and median survival time (10 to 17 months) of large pancreatic cancer [5,21-24]. In the present study, small pancreatic cancer $(\leq 2 \mathrm{~cm})$ was not a factor related to five-year survival after surgical resection for pancreatic cancer on univariate analysis. About a quarter of patients surviving for more than five years had tumors 2 $\mathrm{cm}$ or smaller, suggesting that even patients with a larger tumor can achieve five-year survival.

There are many reports that lymph node metastases are a prognostic factor [4-6]. In addition, the number of positive lymph nodes divided by the total number of lymph nodes evaluated (LNR) has also been reported as a prognostic factor [8]. However, there are few reports limited to the number of lymph nodes. Huebner et al. reported new findings on predictive factors for five-year survival when dividing patients into groups with $\leq 1$ versus $\geq 2$ lymph node metastases [25]. In the present study, actual five-year survivors were limited to patients with two or few lymph node metastases. This result suggested that three or more lymph node metastases may mean that lymph node metastases exist outside the area of dissection, or that distal metastases may be present. 
Table 3 Univariate analysis of factors affecting five-year survival after pancreatectomy for pancreatic adenocarcinoma

\begin{tabular}{|c|c|c|c|}
\hline Characteristics & $\begin{array}{l}\text { Short-term } \\
\text { survivors } \\
(n=129)\end{array}$ & $\begin{array}{l}\text { Five-year } \\
\text { survivors } \\
(n=18)\end{array}$ & $P$ value \\
\hline \multicolumn{4}{|l|}{ Gender } \\
\hline Male & 72 & 13 & 0.21 \\
\hline Female & 57 & 5 & \\
\hline \multicolumn{4}{|l|}{ Age (years) } \\
\hline Median (range) & $67(33-85)$ & $65(46-76)$ & 0.28 \\
\hline \multicolumn{4}{|l|}{ Tumor location } \\
\hline Head & 85 & 12 & 1 \\
\hline Body/tail & 44 & 6 & \\
\hline \multicolumn{4}{|l|}{ Tumor size $(\mathrm{cm})$} \\
\hline Median (range) & $3.5(1.2-18)$ & $3.2(1.2-5.5)$ & 0.52 \\
\hline$\leq 2 \mathrm{~cm}$ & 14 & 5 & 0.06 \\
\hline$>2 \mathrm{~cm}$ & 115 & 13 & \\
\hline \multicolumn{4}{|c|}{ Histologic differentiation } \\
\hline Grade 1-2 & 102 & 11 & 0.13 \\
\hline Grade 3-4 & 27 & 7 & \\
\hline \multicolumn{4}{|l|}{ T classification } \\
\hline$\overline{\mathrm{T} 1-\mathrm{T} 2}$ & 14 & 3 & 0.44 \\
\hline T3-T4 & 115 & 15 & \\
\hline \multicolumn{4}{|l|}{$\mathrm{N}$ classification } \\
\hline No & 49 & 10 & 0.2 \\
\hline N1 & 80 & 8 & \\
\hline \multicolumn{4}{|c|}{ Number of resected lymph nodes } \\
\hline Median (range) & $25(2100)$ & $17(258)$ & 0.51 \\
\hline \multicolumn{4}{|c|}{$\begin{array}{l}\text { Number of lymph node } \\
\text { metastasis }\end{array}$} \\
\hline$\leq 2$ & 95 & 18 & 0.01 \\
\hline$\geq 3$ & 34 & 0 & \\
\hline \multicolumn{4}{|c|}{ CA19-9 level (U/mL) } \\
\hline Median (range) & 172 (223009) & $30.5(23221)$ & 0.02 \\
\hline$\leq 40$ & 34 & 12 & 0 \\
\hline$>40$ & 94 & 6 & \\
\hline \multicolumn{4}{|c|}{ Resection margin } \\
\hline Ro & 58 & 14 & 0.01 \\
\hline $\mathrm{R} 1-\mathrm{R} 2$ & 71 & 4 & \\
\hline \multicolumn{4}{|c|}{ Adjuvant therapy } \\
\hline Yes & 19 & 1 & 0.47 \\
\hline No & 110 & 17 & \\
\hline \multicolumn{4}{|l|}{ Serosal invasion } \\
\hline Present & 81 & 10 & 0.61 \\
\hline Absent & 48 & 8 & \\
\hline \multicolumn{4}{|c|}{ Retroperitoneal invasion } \\
\hline Present & 91 & 11 & 0.58 \\
\hline Absent & 36 & 6 & \\
\hline
\end{tabular}

Table 3 Univariate analysis of factors affecting five-year survival after pancreatectomy for pancreatic adenocarcinoma (Continued)

Intrapancreatic common bile

duct invasion

\begin{tabular}{llll}
\hline Present & 61 & 7 & 0.62 \\
\hline Absent & 68 & 11 & \\
\hline Lymphatic permeation & & & \\
\hline Present & 113 & 16 & 1 \\
\hline Absent & 16 & 2 & \\
\hline Vascular permeation & & & \\
\hline Present & 63 & 8 & 0.8 \\
\hline Absent & 66 & 10 & \\
\hline Intrapancreatic nerve invasion & & & \\
\hline Present & 118 & 13 & 0.03 \\
\hline Absent & 13 & 5 & \\
\hline Portal vein resection & & & \\
\hline Present & 31 & 2 & 0.37 \\
\hline Absent & 98 & 16 & \\
\hline Intraoperative radiation therapy & & & \\
\hline Present & 11 & 3 & 0.38 \\
\hline Absent & 118 & 15 & \\
\hline
\end{tabular}

In the present study, a CA19-9 cutoff value of $40 \mathrm{U} / \mathrm{mL}$ was established using ROC curve analysis as described in the statistical section. The AUC of 0.67 at the cutoff value may be statistically insufficient for sensitivity and specificity, however, it was optimal in our data. Abnormally elevated CA19-9 levels have been reported as a prognostic factor in previous studies, but the cutoff values have ranged widely from 30 to $1,000 \mathrm{U} / \mathrm{mL}$. The normal value for CA19-9 is $\leq 37 \mathrm{U} / \mathrm{mL}$, and interestingly, a CA19-9 of $\leq 40 \mathrm{U} / \mathrm{mL}$ (near the normal value) was associated with

Table 4 Multivariate analysis of factors affecting five-year survival after pancreatectomy with invasive carcinoma of the pancreas

\begin{tabular}{llll}
\hline Predictors & $\begin{array}{l}\text { Odds } \\
\text { ratio }\end{array}$ & $\begin{array}{l}\text { 95\% confidence } \\
\text { interval }\end{array}$ & P value \\
\hline Number of lymph node metastasis & & & \\
\hline$\leq 2$ & 6.02 & $1.08-112.98$ & 0.0385 \\
\hline$\geq 3$ & 1 & & \\
\hline CA-19-9 level $(\mathrm{U} / \mathrm{mL})$ & & & \\
\hline$\leq 40$ & 5.02 & $1.68-16.48$ & 0.0036 \\
\hline$>40$ & 1 & & \\
\hline Resection margin & & & \\
\hline R0 & 3.63 & $1.12-14.28$ & 0.0316 \\
\hline R1-R2 & 1 & & \\
\hline Intrapancreatic perineural invasion & & & \\
\hline Absent & 2.72 & $0.645-10.86$ & 0.1664 \\
\hline Present & 1 & & \\
\hline
\end{tabular}




\begin{tabular}{cccc}
\hline $\begin{array}{c}\text { Number of } \\
\text { predictors }\end{array}$ & $\mathrm{n}$ & $\begin{array}{c}\text { MST } \\
\text { (month) }\end{array}$ & $\begin{array}{c}\text { 5-year survival } \\
\text { rate(\%) }\end{array}$ \\
\hline 0 & 16 & 8.6 & 0 \\
1 & 53 & 8.2 & 2.3 \\
2 & 59 & 17.0 & 11.9 \\
3 & 19 & 39.0 & 42.1 \\
\hline
\end{tabular}

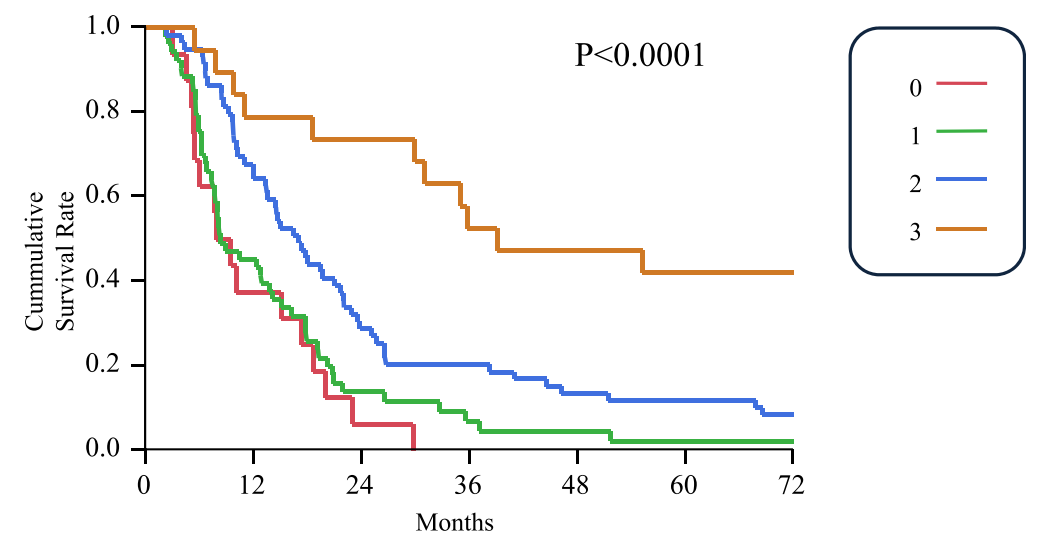

Figure 2 A combined analysis of the preoperative serum CA19-9 level, R0 resection, and number of lymph node metastases being two or less. The subgroup of preoperative serum CA19-9 $\leq 40 \mathrm{U} / \mathrm{mL}$ and R0 resection, together with number of lymph node metastases $\leq 2$, is associated with a probability of five-year survival of $42.1 \%$. MST, median survival time.

five-year survival in the present study. Waraya et al. reported cutoff values of $28 \mathrm{U} / \mathrm{mL}$ or $30 \mathrm{U} / \mathrm{mL}$ in terms of prognosis, which supports the current results [9]. These results might suggest that long-term survival after surgical resection for pancreatic ductal carcinoma requires that the preoperative CA19-9 level be around the normal range. No other tumor markers, including CEA (Carcinoembryonic antigen) and DUPAN-2, were useful as prognostic indicators (data not shown).

Resection status has also been often reported as a prognostic factor. The present study also found residual tumor status to be an independent predictive factor related to five-year survival. On the other hand, retroperitoneal invasion was not a predictive factor for five-year survival. This important finding means that, even in cases with retroperitoneal invasion, R0 resection is important and hopeful for five-year survival.

In addition, four patients had tumor recurrence beyond five years of follow-up. The longest interval to recurrence was 8.7 years, with lung and skin metastases. Therefore, it should be kept in mind during the followup period that recurrences may occur even after five years. Schnelldorfer et al. reported that none of the 30 patients who survived beyond 7.8 years had recurrence of disease, and all survived beyond 10 years [6]. Katz et al. also reported that late recurrence after five years occurred in seven patients and the latest cancer-related death occurred at 7.6 years [26]. In consideration of our report and the previous reports, survival beyond 10 years might suggest a potential cure.

The CONKO-001 trial [27] reported gemcitabine to be effective as a postoperative adjuvant therapy. This trial reported that treatment with adjuvant gemcitabine led to a $24 \%$ improvement in overall survival, with a significant 10.3 percentage point absolute improvement in the five-year overall survival rate (20.7 versus $10.4 \%$ ), compared with observation alone. Moreover, a recent phase three study compared S-1 and gemcitabine as postoperative adjuvant therapy and reported S-1 to be superior. In this study, in the S-1 therapy group, median relapse-free survival time was 23.2 months, and the two-year relapsefree survival rate was $49 \%$ [28]. These results strongly suggest that adjuvant chemotherapy achieved long-term survival after surgical resection. However, in the present study a small number of 20 patients received gemcitabine as adjuvant therapy, resulting in no impact of adjuvant therapy on the survival time (Table 3). Since gemcitabine and S-1 have been recently recognized as standard adjuvant therapies after pancreatectomy for pancreatic cancer with the above mentioned evidences [27,28], the rate of adjuvant therapy using either of the two drugs has gradually increased in Japan. Nowadays more than $80 \%$ of the 
patients with pancreatic cancer are given gemcitabine or S-1 after pancreatectomy in our institution. With increasing use of adjuvant therapy for pancreatic cancer in the future, five-year survivors would be expected to increase. Although neoadjuvant chemotherapy and neoadjuvant chemoradiotherapy for pancreatic cancer have been investigated for last two decades, their survival benefit has still not been proven [29,30]. At our institution, neoadjuvant chemoradiotherapy with gemcitabine and S-1 have been used since 2013 for unresectable and borderline resectable pancreatic adenocarcinoma. In our series, some initially unresectable cases have been resectable. But several years are needed to evaluate whether neoadjuvant chemoradiotherapy will become a prognostic factor or not.

Using the predictive model, the subgroup of preoperative serum CA19-9 level cutoff of $40 \mathrm{U} / \mathrm{mL}$ and R0 resection, together with number of lymph node metastases being two or less, is associated with a probability of fiveyear survival of $42.1 \%$ (Figure 2). Although long-term survival in this subgroup can be strongly expected, R0 resection and two or fewer lymph node metastases were post-resection parameters. This result suggests that patients not expected to have these factors at the time of preoperative diagnosis should have neoadjuvant treatment or stronger adjuvant chemotherapy.

The limitations of the present study are as follows. This was a retrospective study conducted at a single institution. Approximately 5 to $10 \%$ of the general population is Lewis antigen A and B-negative, which means that they do not synthesize the CA19-9 antigen and will not have elevated levels, even with pancreatic cancer or other malignancies. In the present series, the data related to Lewis antigens $A$ and $B$ could not be included because of the retrospective nature of the study.

\section{Conclusions}

In conclusion, the present study showed that two or fewer lymph node metastases, a preoperative serum CA19-9 level of $40 \mathrm{U} / \mathrm{mL}$ or less, and $\mathrm{R} 0$ resection were associated with five-year disease-free survival of patients with pancreatic cancer who underwent surgical resection. Patients with these three factors are expected to have a high five-year survival rate after surgical resection of pancreatic carcinoma.

\section{Abbreviations}

AUC: Area under the curve; CA19-9: Carbohydrate antigen 19-9; $\mathrm{CH}$ : Intrapancreatic common bile duct invasion; Cl: Confidence interval; IORT: Intraoperative radiation therapy; LY: Lymphatic invasion; NE: Intrapancreatic nerve invasion; OR: Odds ratio; PV: Portal vein invasion; ROC: Receiver operating characteristics; RP: Retroperitoneal tissue invasion $\mathrm{S}$ : Serosal invasion; V: Venous invasion.

\section{Competing interests}

The authors declare that they have no competing interests.

\section{Authors' contributions}

KK designed the studies and performed the manuscript. RA and BN supported with design and interpretation of this study. Statistical analysis was performed by $\mathrm{MO}$ and SY. KH and AM helped to draft the manuscript. $\mathrm{KM}, \mathrm{KN}$ and TH carried out the catamnestic followup. Overall supervision of the manuscript was completed by KH. All authors read and approved the final manuscript.

\section{Author details}

'Department of Surgical Oncology, Osaka City University Graduate School of Medicine, 1-4-3 Asahimachi, Abeno-ku, Osaka 545-8585, Japan. ${ }^{2}$ Department of Surgery, Kashiwara Municipal Hospital, 1-7-9 Hozenji, Kashiwara City, Osaka 582-0005, Japan.

Received: 9 February 2014 Accepted: 6 November 2014 Published: 27 November 2014

\section{References}

1. Siegel R, Naishadham D, Jemal A: Cancer statistics, 2012. CA Cancer J Clin 2012, 62:10-29.

2. Matsuno S, Egawa S, Fukuyama S, Motoi F, Sunamura M, Isaji S, Imaizumi T, Okada S, Kato H, Suda K, Nakao A, Hiraoka T, Hosotani R, Takeda K: Pancreatic Cancer Registry in Japan: 20 years of experience. Pancreas 2004, 28:219-230

3. Zuckerman DS, Ryan DP: Adjuvant therapy for pancreatic cancer: a review. Cancer 2008, 112:243-249.

4. Zacharias T, Jaeck D, Oussoultzoglou E, Neuville A, Bachellier $P$ : Impact of lymph node involvement on long-term survival after RO pancreaticoduodenectomy for ductal adenocarcinoma of the pancreas. J Gastrointest Surg 2007, 11:350-356.

5. Lim JE, Chien MW, Earle CC: Prognostic factors following curative resection for pancreatic adenocarcinoma: a population-based, linked database analysis of 396 patients. Ann Surg 2003, 237:74-85.

6. Schnelldorfer T, Ware AL, Sarr MG, Smyrk TC, Zhang L, Qin R, Gullerud RE, Donohue JH, Nagorney DM, Farnell MB: Long-term survival after pancreatoduodenectomy for pancreatic adenocarcinoma: is cure possible? Ann Surg 2008, 247:456-462.

7. Ferrone CR, Brennan MF, Gonen M, Coit DG, Fong Y, Chung S, Tang L, Klimstra D, Allen PJ: Pancreatic adenocarcinoma: the actual 5-year survivors. J Gastrointest Surg 2008, 12:701-706.

8. Hartwig W, Hackert T, Hinz U, Gluth A, Bergmann F, Strobel O, Buchler MW Werner J: Pancreatic cancer surgery in the new millennium: better prediction of outcome. Ann Surg 2011, 254:311-319.

9. Waraya M, Yamashita K, Katagiri H, Ishii K, Takahashi Y, Furuta K, Watanabe M: Preoperative serum CA19-9 and dissected peripancreatic tissue margin as determiners of long-term survival in pancreatic cancer. Ann Surg Oncol 2009, 16:1231-1240.

10. Ferrone $C R$, Finkelstein DM, Thayer SP, Muzikansky A, Fernandez-delCastillo C, Warshaw AL: Perioperative CA19-9 levels can predict stage and survival in patients with resectable pancreatic adenocarcinoma. J Clin Oncol 2006, 24:2897-2902.

11. Hallemeier CL, Botros M, Corsini MM, Haddock MG, Gunderson LL, Miller RC: Preoperative CA 19-9 level is an important prognostic factor in patients with pancreatic adenocarcinoma treated with surgical resection and adjuvant concurrent chemoradiotherapy. Am J Clin Oncol 2011, 34:567-572.

12. Adham M, Jaeck D, Le Borgne J, Oussoultzouglou E, Chenard-Neu MP, Mosnier JF, Scoazec JY, Mornex F, Partensky C: Long-term survival (5-20 years) after pancreatectomy for pancreatic ductal adenocarcinoma: a series of 30 patients collected from 3 institutions. Pancreas 2008, 37:352-357.

13. Cleary SP, Gryfe R, Guindi M, Greig P, Smith L, Mackenzie R, Strasberg S, Hanna S, Taylor B, Langer B, Gallinger S: Prognostic factors in resected pancreatic adenocarcinoma: analysis of actual 5-year survivors. J Am Coll Surg 2004, 198:722-731.

14. Shimada K, Sakamoto Y, Nara S, Esaki M, Kosuge T, Hiraoka N: Analysis of 5-year survivors after a macroscopic curative pancreatectomy for invasive ductal adenocarcinoma. World J Surg 2010, 34:1908-1915.

15. Gordon TA, Burleyson GP, Tielsch JM, Cameron JL: The effects of regionalization on cost and outcome for one general high-risk surgical procedure. Ann Surg 1995, 221:43-49. 
16. Ho V, Heslin MJ: Effect of hospital volume and experience on in-hospital mortality for pancreaticoduodenectomy. Ann Surg 2003, 237:509-514.

17. Sosa JA, Bowman HM, Gordon TA, Bass EB, Yeo CJ, Lillemoe KD, Pitt HA, Tielsch JM, Cameron JL: Importance of hospital volume in the overall management of pancreatic cancer. Ann Surg 1998, 228:429-438.

18. SLaW C: TMN Classification of Malignant Tumours. 6th edition. New Jersey: John Wiley and Sons Ltd; 2002.

19. Bosman ESJ FT, Lakhani SR, Hiroko O: WHO Classification of Tumours of the Digestive System. Lyon: International Agency for Research on Cancer; 2010.

20. Japanese Pancreas Society: General Rules for the Study of Pancreatic Cancer 6th edition. Tokyo: Kanehara-syuppan; 2009.

21. Meyer W, Jurowich C, Reichel M, Steinhauser B, Wunsch PH, Gebhardt C: Pathomorphological and histological prognostic factors in curatively resected ductal adenocarcinoma of the pancreas. Surg Today 2000, 30:582-587.

22. Pantalone D, Ragionieri I, Nesi G: Improved survival in small pancreatic cancer. Dig Surg 2001, 18:41-46.

23. Pongprasobchai S, Pannala R, Smyrk TC, Bamlet W, Pitchumoni S, Ougolkov A, de Andrade M, Petersen GM, Chari ST: Long-term survival and prognostic indicators in small $(<0 r=2 \mathrm{~cm})$ pancreatic cancer. Pancreatology 2008, 8:587-592

24. Yeo CJ, Cameron JL, Lillemoe KD, Sitzmann JV, Hruban RH, Goodman SN, Dooley WC, Coleman J, Pitt HA: Pancreaticoduodenectomy for cancer of the head of the pancreas: 201 patients. Ann Surg 1995, 221:721-731. discussion 731-723.

25. Huebner M, Kendrick M, Reid-Lombardo KM, Que F, Therneau T, Qin R Donohue J, Nagorney D, Farnell M, Sarr M: Number of lymph nodes evaluated: prognostic value in pancreatic adenocarcinoma. J Gastrointest Surg 2012, 16:920-926.

26. Katz MH, Wang H, Fleming JB, Sun CC, Hwang RF, Wolff RA, Varadhachary G, Abbruzzese JL, Crane CH, Krishnan S, Vauthey JN, Abdalla EK, Lee JE, Pisters PW, Evans DB: Long-term survival after multidisciplinary management of resected pancreatic adenocarcinoma. Ann Surg Oncol 2009, 16:836-847.

27. Oettle H, Neuhaus P, Hochhaus A, Hartmann JT, Gellert K, Ridwelski K, Niedergethmann M, Zulke C, Fahlke J, Arning MB, Sinn M, Hinke A, Riess H: Adjuvant chemotherapy with gemcitabine and long-term outcomes among patients with resected pancreatic cancer: the CONKO-001 randomized trial. JAMA 2013, 310:1473-1481.

28. Uesaka K, Fukutomi A, Boku N, Kanemoto M, Konishi I, Matsumoto Y, Shimizu S: Randomized phase 3 trial of adjuvant chemotherapy with gemcitabine vs. S-1 for resected pancreatic cancer (JASPAC-01 study). J Clin Oncol 2013, 31(4s):abst145.

29. Reni M: Neoadjuvant treatment for resectable pancreatic cancer: time for phase III testing? World J Gastroenterol 2010, 16:4883-4887.

30. Festa V, Andriulli A, Valvano MR, Uomo G, Perri F, Andriulli N, Corrao S, Koch M: Neoadjuvant chemo-radiotherapy for patients with borderline resectable pancreatic cancer: a meta-analytical evaluation of prospective studies. JOP 2013, 14:618-625.

doi:10.1186/1477-7819-12-360

Cite this article as: Kimura et al: Clinical and pathological features of five-year survivors after pancreatectomy for pancreatic adenocarcinoma.

World Journal of Surgical Oncology 2014 12:360

\section{Submit your next manuscript to BioMed Central and take full advantage of:}

- Convenient online submission

- Thorough peer review

- No space constraints or color figure charges

- Immediate publication on acceptance

- Inclusion in PubMed, CAS, Scopus and Google Scholar

- Research which is freely available for redistribution 